\title{
Causes and Effects of Online Video Game Playing among Junior-Senior High School Students in Malang East Java
}

Komunitas: International Journal of Indonesian Society and Culture 9(2) (2017): 191-202

DOl:10.15294/komunitas.v9i2.9565 (C) 2017 Semarang State University, Indonesia p-ISSN 2086 - 5465 | e-ISSN 2460-7320 http://journal.unnes.ac.id/nju/index.php/komunitas

\author{
I Dewa Putu Eskasasnanda ${ }^{1}$ \\ ${ }^{1}$ Social Studies Department, Universitas Negeri Malang, Indonesia
}

Received: July 2016; Accepted: August 2016; Published: September 2017

\begin{abstract}
Science and technology development causes a lot of changes in any fields including the form of popular games among the Junior and Senior High School students in Indonesia. The traditional games that are famous formerly have been replaced by the modern games like online video game. This article discusses the cause and effect of the online video game playing on the Junior and Senior High Schools students in Malang. This study reveal that students play video games online due to peers pressure; and online video games are liked because they are considered more modern, practical, realistic and varied. Initially, students play online video games to relieve the fatigue due to studying at school, but subsequently, they are becoming addicted, and reach a condition that they find it difficult to stop playing games. This condition will directly affect their achievement in school.
\end{abstract}

\section{Keywords}

online video games; cause; effect

\section{INTRODUCTION}

Playing is very important especially for young people because it can prepare their future. According to the Anthropological study done by Gosso, play is way for human to learn their world and culture. Through playing, children do not learn only future adult skill but also gender identification courage, trust among friend and cooperation (Gosso 2005). Groos and Piaget say that humans use play to prepare their adult life (Groos 1908; Piaget \& Inhelder 1969). Hall also say that play is used by humans to identify their world. Through play human interacts with their physical and social world to establish their mentality (Hall 1916). For example, when girls playing with a broom to imitate mother cleaning the house, she also learns the role of becoming a housewife. Boy who roams in the river looking for fish, he actually also learn to recognize beneficial or harmful flora and fauna in the nature. Playing game in a group also make children aware about their physical strenghth, capability, superiority, seniority, cooperation benefit, leadership skills and sympathy-empathy.

Playing game also important in children physical fitness and creativity. Traditional game that based on physical activity is important to develop children

\footnotetext{
Corresponding author

Perumahan Joyogrand Blok LL-8 Merjosari Lowok-

waru Kota Malang, Indonesia

Email

dewa.putu.eskasasnanda.fis@um.ac.id
} 
muscle. Since traditional games usually utilizing handmade equipment, it can develop children brain creativity. A wooden stick used to play hit the ball, banana stems and tires made into swimming buoys are some example of children's creativity.

Online video games are now popular among children especially to junior-senior high school students in many town in Indonesia. In Malang East Java, in the afternoon, after students getting back from school, up to late night a lot of junior-senior high school students playing online video games in internet cafes (warnet). On Sundays or other holidays, internet cafes are also usually full of students who play online video game and this situation sometime makes adult customers difficult to rent a computer. The popularity of online video games makes students prefer to spend their time playing online video game than doing outdoor activities. This makes city parks and football fields becoming quite, vacant and deserted.

Closely related with this phenomenon, a study on the cause and effect of online video game consumption among student is urgent to carry out. This is due to the anxiety of many parties concerning the online video games impacts in decreasing student creativities, fitness and other forms of social skilsl. In online video games, all equipments, rules and playforms are created by their creators. This make students feels don not need to be creative in playing the games. Online video games also cause their players wasting or using up a lot of their time sitting in front of the computer screens. This acitivity could in turn make students loosing their physical fitness and social skill because they will never notice their physical and social surroundings. The condition will eventually bring various fatal effects for their physical and mental developments (Van Rooij et al. 2011; Mehroof \& Griffiths 2010; Przybylski et al. 2010).

\section{ONLINE VIDEO GAME}

Video game according to Bogdanowicz et als. (2010), is defined as " an electronic or computerized game played by manipulating images on a video display or television screen". Online video games are popularamong students and they are used them as a means for them to be accepted by their peers. Peer pressures according to Erikson have great impact on the life of an adolescence. Erikson said that in adolescence phase, person is required to seek self-identity and independence (Erikson 1968). When they try to get free from all adult influence and protection, they become closer and more dependent on peer acceptance. Peer acceptance brings out pressure that in turn can make the adolecences vulnerable to youth behavioral problems (Allen et al. 2006; Van Rooij et al. 2011; Porter et al. 2010).

Another reason that makes online video games becoming popular among students is because these games are sophicastedly designed to amaze and evoke the players' curiousity. To amaze the players, video games usually presents attractive game plays, realistic images and sounds. Virtual worlds in video games are created by inspiration of real life location. This is intended to provide sensation as if the player is visiting a real site location so they are not easy to get bored and the games also make players becoming familiar and easy to memorize the location.

Bogost and Poremba also find that many video games are also popular because their storyline are based on actual events or movie storylines. Some games even exploit documentary styles to add the authenticity. "The Matrix" movie, allied forces landing in Normady, and the assassination of John Frank Kenedy (JFK) are used by video game creators to make the player enable to imagine becoming the main character of the film or feel that they have a central role in an important world event. Movie storylines and real events are also proposed to familiarize players with the goal of the mission (Bogost \& Poremba 2008).

On his the study about racing video games, Berger says that the actual based race track is getting more fans than imaginary one. Even, imaginary race track are design to create fair race and spectacular, actually authentic based race track gives more 
fun for the players. Berger said that this is due to the sensation of be a real race driver and win the world championship. Playing in the imaginary track in contrast, makes the players get bored and leave the game immediately because the players felt it useless (Berger 2008).

Video games are also enjoyed because it is designed to entertain and amuse the players. Creators make video game storyline simple and easy to understand. This will make the players not easy to get frustated. Players use video games to get fun and and escaping them from life pressures, As such, they will leave the game if they find it too complicated.

To maintain the reasonability of video game playing, creator also must balance the challenges in the game. The game must not too hard or too easy to win. Players do not like easy game because they feel useless to play. However, if the game is too hard, player will get frustrated and they will leave the game. There are also some Strategies used to maintain players' enthusiasm. One of which is by giving game assistance. Assistance such as coin bonus or prize to buy new weapons or vehicles is used by the creator to help player completing the game mission when they encounter difficulties. To keep the video game looks real, any assistance in game must be built in disguised so the players are unaware of it. By this sterategy, Klimnt et als. (2008) said completing one mission in video games can make someone feel worth and proud. so they feel reasonable to continue playing the game.

For most students, another pulling factor of online video games is the economic system that operates in it. Cain shows that many players are interested to play online video games because of the economic system being operated. In online video games there is a virtual currency circulation that is called "coin". Coin is a reward for players when they are able completing a mission. On line video games coins can be accumulated to buy virtual equipment to help finishing the game (Cain 2008). Although every missions gives coin bonus, the reward is usually too small. Game creators always make the pri- ce of virtual equipment so high that players will be motivated to play more or exchange their real life money into virtual coin to buy equipment. Cain also states that the decision of the players to buy coins is not solely inteded for facilitating the game. They do not hesitate to buy expensive virtual equipment because they can sell it back to other players (Cain 2008).

Transaction of virtual equipment in online game create a chance for making money in online game. Through this, it is not surprising that many players are willing to spend a lot of time to look for money. Students are even willing to be absent in class or eventually drop out from school because they prefer playing online games. Coin and virtual transactions in online video game make students think that it is better to play game and get coins that can be sold rather than study in school but never making any money (Olson 2010; Kowert \& Oldmeadow 2013)we must understand what motivates children to play electronic games and what needs the games meet. Drawing on a survey of 1,254 middle school children, focus groups with boys and their parents, and findings from other quantitative and qualitative research, the author describes a variety of motivations for video game play (including games with violent content.

It is not only visualization, game play or economic system that makes online games interesting. Marshall says online video games also enable players to play with virtual bodies (character) that commonly referred to "avatars". In the online video game, players are free to choose an avatar depending on taste and experience they want to get, and image they want to show (Marshall 2008). In online video game an overweight, short, and black player can choose a tall, white and athletic avatar. Men players also possible to choose a women avatar, depending on experience he wants to get during the game. Avatars in video games online provide the opportunity for players to get ideal things that can not be obtained in the real world.

Stone says that online video games make players eliminate their physical identi- 
ty (Stone 1991). In the game, players become a new individual with new behavior. Stone and Turkle calls this phenomenon multiple selves (Turkle 2011; Stone 1991). A person's identity in the real world is formed by his or her interaction with other people and material objects they consume, but in virtual world, the identity is highly fluid, allowing player to rewrite their identity beyond traditional boundaries. With avatar, a man can be a woman's, a poor can wear expensive clothes and a pacifist can kill other because of the video game mission (King et al. 2011; Gentile 2011; Hellman et al. 2012).

\section{The Effect of Online Video Games}

Kücklich says that there are two kinds of video game in the world. The first is "casual game" or video game that is only played for killing time and the second is "serious game", a video game which makes players always curious and force to spend a lot of time to play it (Kücklich 2005). From these two types, the "serious games" is considered more dangerous, because it can make players become a slave of the game which is commonly called "playbour". In a line with Kuklich, Hjorth uses term of "hardcore game" to refer to the serious game. This game is called "hardcore" for its potential to make players spending a lot of time and energy to finish the game (Hjorth 2011).

In online video games, people play in virtual world using avatar (virtual body). Even though the virtual world are a fun but all human beings must always go back to the real world. No matter how great a player might play in the virtual world, his physical body will feel hungry, thirsty and fatigue. So, he should always come back to real life to get a meal, drink and maintain his physical fitness.

Human behaviors are shaped by their experience. The danger of online video games will appears if the experience gained in virtual world affects the real life. Herbs says that many experiences gained during online video playing can not be applied for real life. For example, death in real life is a final event of a person. Contrary, in video games there are no limit how many death player can experience. If avatar die, players can turn it back to life unconditionally to continue playing. off course this experience will become a danger if it is applied in real life (Herbst 2008).

One kind of video game that can bring a seious dangerous for students is violence games. In violence games such as war games, players are required to kill all enemies. Death, explosions, screams and gun shoot constantly and repetedly happen. War games are more bloody and sadistic than any kind of action film. In war game, players do not have time to think. He must kill all enemy without thinking of grief. There are no smell of blood, smoke and gun powder. There are no time of silence to think about the tragedy of the murders. In war game, players are built like a machines, and responding quickly all the action of the game. War game is designed not to create a feeling of love, compassion or sentimental feelling in the players.

Klimnt et al. (2008) said that violence game are enjoyable especially for human male because the culture is idealized hypermasculine gender ideal. Violence is perceived as manly. Hyper-male ideology believes in socioevolutionary theory says that only the strong will survive. Destruction on virtual world can be beneficial if it is used properly like a channel to safely release anger and aggression. There will be no one harmed because blood, fire and debris in online video games are only pixelwork, and all experiences are simulated and virtual. The negative thing will occur if a player apply violent experience in virtual world to the reality. In this case Klimnt suggests that heavy users of violent video games should posses a higher cognitive 'preparedness' for over riding moral concerns as well as for avoiding violent behaviours in real life.

The other positive side of online video game is proposed by Dyson. In busy life of urban communities, people are isolated from each other. On line video games provide space for children to interact with others. In dense urban population that prone to criminality, playing online video games indoor at home or internet cafe is relati- 
vely safer than letting them playing outside. Indoor playing will protect children from the danger of traffic, sun heat, and air pollution. Children are also protected from criminality, kidnappings, harassment and bullying by older children who are bigger and stronger than them (Dyson 2008). This research aims at finding the causes and effects of online video games carried out by junior-senior high students in Malang city, East java province.

Online video games are favored by various groups ranging from todler, students in elementary school up to university students and adults. This research will study junior and senior high school students because the majority of video game players online is a junior-senior high school students. According to Nicolson and Ayers (2004) junior-senior high school period is the age of adolescence or transition between children into adult. This phase begins around the age of 10-13 years and ends at age of 18-22 years. At this phase a person experiences biological, social, emotional and cognitive development. If the adolescence phase is not addressed satisfactorily, it can lead to behavioral problems in the future.

This research is conducted in Malang City, East Java Province. Interviews are done using Junior and senior high school student as informants. The Informants are selected through a purposive and snowball sampling. Senior-Junior high schools at Malang are selected based on criteria of public-private and favorite and non favorite school. Based on this criteria, Malang 1 junior and Malang 1 Senior high school are choosen to represent favorite public school. Meanwhile, Malang 10 junior and Malang 16 senior high represent non-favourite school and $\mathrm{Mu}-$ hammadiyah 1 junior and Brawijaya Smart School (BSS)'s senior high is representatives of private schools.

\section{Motivation}

Based on interviews to eight junior-senior high school students, it gains that students know online video games from their peers, such as school friends, brothers or cousins whose parents have a internet cafe business.
I tried to play games because my friends asked me to try it. In school more and more of my friends played online games and these made me becoming more interested. There were a lot of my friends playing online video games so it became more excitings and I wanted to try it (interview with $\mathrm{Nr}$, 1 Malang Senior High School July 16, 2013)

I started playing online game at the 5 th grade elementary, this because I followed my cousin. My cousin introduced me to online video games because his parent operated internet café in his house. I played online games starting from there, and continued until now (interview with Ad, 1 Malang Junior High School, July 18, 2013)

Beside the influence of the peer, there are students who inform that the become interested to play online video games because often watch online video games commercial banner displayed in front of internet cafe. His motivation to try online video games increased when internet cafés also offered one hour free trial play.

I knew $P B$ (point blank) online games when I was in six grade elementary. It started when I was passing through the internet cafe near my house, I saw commercial banners which offered one hour free trial to play online game. I asked to the internet caffe operator then he I gave one hour free trial. I continued to play up till now because it is enjoyable (interview with Af, 16 Malang Junior High School, July 17, 2013)

Peer pressures have a big deal of cause for student trying online video games. Two students said that there were sense of inferiority if they did not know how to play online video games. Students would be considered outdated and coward if they resisted the challenge of friends to play online video games.

I play online video games in order not to be ridiculed by my friends. For example when my friend challenged me to play 
online video game, I must accept it. otherwise my friend would considerd me coward. (interview with Ik, 16 Malang Junior High School, July 15, 2013)

I played online video game because friend encouraged me. They considered me backward if did not know about the game. At first I felt clumsy because I never played the game. I did not have any computer in my house. Now I couldn adapt and became one of the best player among my friend (interview with $\mathrm{Au}, 1$ Malang Junior High School, July 19, 2013)

When student went to internet café, they got amazed by realistic image and sound displayed by online video games. Student said that he got interested when they saw the excitement of many people playing online video games in internet café.

Online game playing was interesting and exciting. When I was at the first time see people play it, I was interested and want to try because it looks exciting. up until now I still play it ( interview with Ad, 1 Malang Junior High School July 18, 2013 )

\section{Passions on Online Video Games}

Acording to student oppinion, online video game is exciting because it is always updated and has more variations than the traditional game they used to play.. Traditional games is considered monotonous because they do not undergo many innovations.

I think the good thing of online video games is that it is always being updated every month or might be every day. Accordingly, we never get bored. Contrary, playing traditional games is boring because it $s$ monotonous and no innovation in it (interview with Fa, 1o Malang Senior High School, July 18, 2013)

Online video games are also considered modern for student because these games allow them interacting with a broader range of people, not only with school peers and neighbours but also people outside the town or even the country.
I think if we play modern games we would become modern because we can interact with people all over the world not only with the local (interview with Qa, 1 Muhammadiyah junior High School, July 17, 2013)

The fun of online video game is its possibility to interact with better friend. I can make contact with the rich and wealthy people from all over the places not only with poor and backward village people in my neighbourhood (interview with Af, 16 Malang Junior High School, July 17, 2013)

Another reason that makes online video games interesting is because of the score that can be collected by any players. In traditional games, there are no score to obtain. As such, student cannot claim who the best player is. In online video games, score can colected as indicator of the player's skill.

The nice feature of online game is the rank system. If we play the game seriously and win frequently, we will improve our score and ranks. By this rank we can claim who the best player is in the game. In traditional game no ranking system is used because itis just for fun (interview with $\mathrm{Fd}, 16$ Malang Junior High School, July 15, 2013 )

In online video games, young players are possible to beat the older ones. In this case students say that they feel proud and motivated when can beat older player. Beating older players such as college student is very pleasant. This is impossible to achieve in traditional games that is only relied on physical strength.

I think, the exciting moment of online video game is when we can beat the older players. I onced beating a college student and it feels terrific and fascinating. This experience enhanced my motivation to play (Ikhwata, 16 Malang Junior High School, July 15, 2013.

Beating older people in online video games issuch an enjoyble experience because we can ridicule and embarrasse them. It is joyful to see them angry (interview with Qa, 1 Muhammadiyah junior High School, July 17, 2013)

UNNES JOURMALS 
Students also like video games because of its practicality. It is not difficult to find partner to play online video games because there is always someone playing in the internet. This is unlike traditional games in that student must gather a lot of friends to play with.

I play online video games when I feel bored at home. I have internet connection and computer set at home so I just connect it to internet and play online games. In traditional games it is not that simple. I must go outside and asking friends door to door to play. I think it's wasting time. In online games I dont need to ask friends to play, I just join people playing in the internet ( interview with Ad, 1 Malang Junior High School, Juli 18, 2013 )

The other advantage of online game is its possibiility to play from home. This is very practical because we don not have to to come out. My parent would also be very angry if I play outside too long. To avoid this, it is better to play at home than I get caught for wandering arround (interview with Ri, 1 Malang Senior High School, July 16, 2013 )

Online video games are not exhausting like traditional games which require player running, jumping or yelling. In online video games player only sit on a chair or sofa in a room or internet café.

The good side of online video games is that this game is not draining my stamina, if I play traditional game, I would get sweat because of jumping and running (interview with Ik, 16 Malang Junior High School, July 15, 2013)

I like online video games beside it brings fun and exciting, it is also neat because I play it in air conditioned room on internet café. (interview with Fa, Brawijaya Smart School, June 20, 2013)

When online video games becoming more and more popular, it becomes very difficult to find students who are still playing traditional games. This condition make students ought to play online video games to get friend.
If I compare it to the traditional game, I think traditional game is more exciting. I become more proud when winning the game because I got it through a great effort. Unfortunately it is getting more and more hard now to play traditional game because nobody plays it anymore (interview with $\mathrm{Fu}$, Brawijaya Smart School, June 20, 2013)

Actually I like and enjoy playing hide and seek and football with my friend but now it is not easy to do it. Everyone now prefer playing online video games in internet café that make me also play online video games (interview with $\mathrm{Au}, 1$ Malang Junior High School, July 19, 2013)

\section{Positive and Negative Effects}

By gathering student oppinion, it is discovered that the positive side is that it can be used as media for brain refresher. Student often feels frustated and exhausted because of school activitie and homework. This condition make them need online video game to get entertainment.

I play online game because I feel exhausted from school activities and homeworks. (interview with Ik, 16 Malang Junior High, July 15, 2013)

Ussualy I play online game when I gets home. School sometimes makes me feel tired and exhausted so I play online game for refesher (interview with Ad, 1 Malang Junior High School, July 18, 2013 )

The negative impact of the online video game happens when students play it too much. Online video game are designed to chalenge and entertain player by realistic image and sound. This often makes student addicted and difficult to stop play it.

The bad side of online game is its effect that sometimes make me difficult to stop playing. Actually my body has already felt tired and I want to take a break, but I cannot do so. The game always makes me feel in the middle of something and I cannot stop. (interview with Ri, 1 Malang Senior High School, 16 July 2013 ) 
Too much playing online game also can make students having hallucinations. One student admitted that he sometimes he got comment from parents bacause of daydreaming while moving fingers like holding mouse and keyboard. Because of online video games, he also sometime gets halucination like seeing creatures that actually does not exist.

Because addicted to the game, my parent said that I was weird. When my parents seized my laptop to prevent me from play online video games, they ever saw me hallucinate with hands move like holding a mouse and keyboard. Because of online video game sometimes I also got hallucinations. It looks like I saw something flying but actualy nothing happen. (interview with $\mathrm{Na}, 1$ Malang Senior High School July 16,2013 )

I try to reduce hours for playing games because it sometimes make me difficult to concentate and give me hallucination. ( interview with Ik, 16 Malang Junior High School, July 15, 2013)

Too much playing online video game make students' physically exhausted. They experience dizzy and back pain because too much sitting and watching computer screen.

Negative side of online game is its impact of making my body feel tired. After playing games I often experience sore eyes, dizzy and back pain because sitting too much (interview with Af, 16 Malang Junior High School, July 17, 2013)

The bad side of online game is make my body feel tired. Playing online video game ussually get my hand feel numb. ( interview with $\mathrm{Au}, 1$ Malang Junior High School, July 19, 2013).

When student physical body are tired because of playing online video games, they afterwards experience difficulty to study in school or to do homework.

Yes I think the negative side of online game sometimes make me difficult to control the length of play. Because of online video games, I often get home too late and tired. So I cannot do my homework. ( interview with Ik, July 19, 2013)

Playing online video game often make me feel tired and lack of sleep. This condition make me sleepy in school. (interview with Qa, 1 Muhammadiyah junior High School, July 17, 2013)

As results, two students experience decline on school academic performance. Before playing online video games they are top ten in the class but after playing online video games they often get the lowest rank.

Online video game make my academic achivement dropped. In elementary school I often got the top three but now I never got it. Eventhough I still in the top ten of the class. (interview with Qa, 1 Muhammadiyah Junior High School, July 17, 2013)

My marks before playing online games are excellent. Often I got one hundred and in the top ten of the class. After playing online game, my school marks went down. Now my rank is 30 out of 40 students. (interview with $\mathrm{Na}, 1$ Malang Senior High School, July 16, 2013)

To overcome the negative effects of online video games, some parents forced his children to join extra tutorial lessons outside the school. The purpose is to improve student school academic performance. From student opinion this strategy is not effective. Students inform that the more they got extra lesson, the more frustated they felt and the stronger their need to play online video games for getting fun.

When my school performance was declining, my parents prohibited me to play online video games. They always inspects me in participating private tutoring. The result I thought was not effective because I can only improve marks on certain subjects. ( interview with $\mathrm{Au}, 1$ Malang Junior High School, July 19, 2013)

Online video games made my parents UNNES JOURNALS 
turned mad. Because my marks were declining they confescated my PC and prohibit me go to the internet cafe. At home I was always ordered to study. I felt bored so I kept on playing online video games. Now I plays it in Internet cafes that are far away from school and house. This to make me difficult to get caught (interview with $\mathrm{Na}$, 1 Malang Senior High School, July 16, 2013)

Even though students are already aware of online video games negative impact, $t$ cannot stop playing online video games easily. Two students said that although online video game often made them tired and lack of money they were unable to stop because it is the only means for getting fun and free from boredom.

Actually I aware that eye games are bad. It is bad for my body, eyes, and mind but I cannot stop it easily because it is the only thing I know to get fun and rid of my boredom (interview with Ri, 1 Malang Senior High School, July 16, 2013)

Yes I conscious that play online game is wasting money but what else can I do. I still need games to release my boredom. (interview with $\mathrm{Au}, 1$ Malang Junior High School, July 19, 2013)

One student said that he cannot leave online video game because he has already played it for long, and woukd feel regret if he must leave the point and achievement that he have been painstakingly collected.

Honestly now I still playing online game now because I already play it. I have a lot of point and in the middle of high level so I feel regret if must stopp it. (interview with Ad, 1 Malang Junior High School, July 18, 2013)

Because the strong need of playing online video games, two students admit that they ever stole money from their parents. They forced to steal money because of the curiousity they get from online video games.

Because of online video game, I have ever done a criminal action, I stole money from my mother purse but I only did it once. Actually I did not get caught but finally I confessed to my parent. My parent got mad but then they forgave me. This incident happened when I was in the second year of junior high school. At that time I stole five hundred thousand rupiahs, but only once, I did not repeat it since then. (interview with Na, 1 Malang Senior High School, July 16, 2013)

Yes I agree if online games can encourage crime. My self ever steal one hundred thoulsand rupiah from my mother. When I get caught, I feel fear because then my father bluff will reported it to the police. I am afraid that police wil jail me. After that incident I learned my lesson, I never steal again eventhough I still play online game up to now (interview with Fa, 16 Malang Junior High School, July 15, 2013)

Regreting of online video game playing only comes after students finish playing it. Student admitted that they realized of spending a great deal of money and savings after they finished playing game. They felt very regretful because the money actually can be used to buy food or other valuable necessities.

Actually I felt regretful for my money expene to play online video game. For example with fifty thousand rupiah, actually I can buy food such as meatbals or buy something useful. If I play online game I only got dizzy and back pain. Even so, it is so difficult to abandon this game" (interview with Qa, 1 Muhammadiyah junior High School, July 17, 2013)

When play online game I sometimes feel a sense of regret. The main reason is the loss of money for nothing. (interview with Ad, 1 Malang Junior High School, July 18, 2013)

\section{ADDICTION}

This research reveals that the main factor underlies online video games played among junior-senior high school students is peer pressure. Students know and then are inter- 
ested to play online video games because of peers. Students who does not know about online video games will be difficult to get friends. They will be regarded as outdated and outmoded. They Student will also be considered coward if they do not respond to the challenge of friend to play online video game. Peer pressure urges students creating account and then learn to play online video games.

After getting used of online video games, students tend to abandon traditional game. The reasons underlie these phenomona are: 1) On line video game is practical. It can be played from home and internet cafes. In internet games, there must be other people who are ready to play with, so they do not need to gather friends. 2) On line video game is not draining stamina because it can be played without running, screaming and yelling. 2). online video game is exciting because it has realistic image and sound. 3) On line video game has various type and not monotonous because it is always evolved and 4) online video game considered modern and enable person interact ing with people all over the world via chatting.

Through this research also, it is also obtained information that the students enjoy online video games because it allows them beating older players. Beating older players is very important for students. Orpen and King explain that feedback or recognition from someone who are considered more experienced or superior is very rewarding because it can improve person confidence (Orpen \& King 1989).

Students play online video games to overcome boredom because of school activities and homework. In this phase online video game have positive side. Online video games become negative when students play it excessively then make them ran out energy and time to study and to do homework. The result is the decline of student school academic performance.

The reason why students play online video games excessively is because they carried away with the form, audio and visualization in online video games. This findings strenghtened many expert studies that online video games are intentionally designed to make players curious and addicted (Klimmt et al. 2008; Berger 2008; Bogost \& Poremba 2008; Dyson 2008; Griffiths 2010; Van Rooij et al. 2011).

According to Schaef there are two forms of addiction in the world, the first one is substance addiction or manipulation of pleasure through the use of products, substances or certain materials which are inserted in the body (eg, narcotics, cigarettes, fast food), the second, is process of addiction or addiction to mood altering behavior (Schaef 1988). Excessive online video game can be categorized as process addiction because it make person becoming dependent on it. They wanted to play online games repeatedly beyond the actual needs in order to eliminate anxiety (Brewer \& Potenza 2008).

When students experienced online video games addiction they experienced regret. they felt regretful for wasting a lot of money to play online video games, not to buy food or other important necessities. Online video game addiction also pushes some students do petty crime such as stealing money from parents.

Even though student know the negative effects of online video games they can not easily stop their hobby. Besides the charm of online video games, student admits that online video games is the only intertainment media around and also a tool to find friend to play with. Nowadays traditional games are rarely played by children, it is getting harder to find a friend to play out door games.

This research also found that the more students exhausted from study, the greater desire to play online video games. Accodringly, parent intervention forcing students to join private tutoring is not effective. This only will make student lying their parents and playing video games online behind their back. Fatigue to study experienced by students (student burnout) according to Maroco and Campos is not only caused by physical exhaustion and psychological for learning activities but also due to doubt or cynicism towards the benefits of learning in 
schools (Maroco \& Campos 2012).

\section{CONCLUSION}

Based on the research findings, it can be deduced that peer pressure is the leading factor students playing online video games. Student who never played online video games can be considered outdated and cowards. Then they will exiled from peer association. When students see their peer playing online video games, they become interested because the thrill, excitement and audio-visual presented in online video game.

Playing online video game is positive when it is used only as a form of entertainment, relaxation, and to drive out boredom from school exhaustion. Playing online video games becomes negative when students are addicted and play it excessively. This is indicated by students who spend a lot of money, time and energy to play it. Unfortunetely, students feel regretful of online video games excessive consumption after experiencing money lavishnes, physical fatigue and decline in school academic performance .

\section{REFERENCES}

Allen, J.P., Porter, M.R. \& McFarland, F.C., 2006. Leaders and followers in adolescent close friendships: Susceptibility to peer influence as a predictor of risky behavior, friendship instability, and depression. Development and psychopathology, 18(1), pp.155-172.

Berger, P., 2008. There and Back Again: Reuse, signifiers and consistency in created game spaces. In Computer Games as a Sociocultural Phenomenon. Springer, pp.47-55.

Bogost, I. \& Poremba, C., 2008. Can Games Get Real? A Closer Look at "Documentary" Digital Games. In Computer Games as a Sociocultural Phenomenon. Springer, pp.12-21.

Brewer, J.A. \& Potenza, M.N., 20o8. The neurobiology and genetics of impulse control disorders: relationships to drug addictions. Biochemical pharmacology, 75(1), pp.63-75.

Cain, J.P., 2008. Another bricolage in the wall: Deleuze and teenage alienation. In Computer Games as a Sociocultural Phenomenon. Springer, pp.5665.

Dyson, L., 2008. Teenage girls "play house”: The cyberdrama of The Sims. In Computer Games as a
Sociocultural Phenomenon. Springer, pp.197206.

Erikson, E.H., 1968. Identity: Youth and Crisis. New York: WW NortonECompany, Inc.

Gentile, D.A., 2011. The Multiple Dimensions of Video Game Effects. Child Development Perspectives.

Griffiths, M.D., 2010. The role of context in online gaming excess and addiction: Some case study evidence. International Journal of Mental Health and Addiction, 8(1), pp.119-125.

Groos, K., 1908. The play of man, D. Appleton.

Hall, G.S., 1916. Adolescence: Its psychology and its relations to physiology, anthropology, sociology, sex, crime, religion and education. Appleton.

Hellman, M. et al., 2012. Is there such a thing as online video game addiction? A cross-disciplinary review. Addiction Research \& Theory.

Herbst, C., 2008. Programming violence: Language and the making of interactive media. In Computer Games as a Sociocultural Phenomenon. Springer, pp.69-77.

Hjorth, L., 2011. Games and gaming: An introduction to new media. Berg.

King, D.L., Delfabbro, P.H. \& Griffiths, M.D., 2011. The Role of Structural Characteristics in Problematic Video Game Play: An Empirical Study. International Journal of Mental Health and Addiction.

Klimmt, C. et al., 2008. “Moral Management”: Dealing with Moral Concerns to Maintain Enjoyment of Violent Video Games. In Computer Games as a Sociocultural Phenomenon. Springer, pp.108-118.

Kowert, R. \& Oldmeadow, J.A., 2013. (A)Social reputation: Exploring the relationship between online video game involvement and social competence. Computers in Human Behavior.

Kücklich, J., 2005. Precarious playbour: Modders and the digital games industry. fibreculture, 5(1).

Maroco, J. \& Campos, J.A.D.B., 2012. Defining the student burnout construct: A structural analysis from three burnout inventories. Psychological reports, 111 (3), pp.814-830.

Marshall, N., 2008. Borders and Bodies in City of Heroes:(Re) imaging American Identity Post 9/11. In Computer Games as a Sociocultural Phenomenon. Springer, pp.140-149.

Mehroof, M. \& Griffiths, M.D., 2010. Online gaming addiction: the role of sensation seeking, selfcontrol, neuroticism, aggression, state anxiety, and trait anxiety. Cyberpsychology, behavior and social networking.

Olson, C.K., 2010. Children's motivations for video game play in the context of normal development. Review of General Psychology.

Orpen, C. \& King, G., 1989. Effects of superiors' feedback, credibility, and expertise on subordinates' reactions: An experimental study. Psychological Reports, 64(2), pp.645-646.

Piaget, J. \& Inhelder, B., 1969. The psychology of the child, Basic books.

Przybylski, A.K., Rigby, C.S. \& Ryan, R.M., 2010. A mo- 
tivational model of video game engagement. Review of General Psychology.

Van Rooij, A.J. et al., 2011. Online video game addiction: Identification of addicted adolescent gamers. Addiction.

Schaef, A.W., 1988. When society becomes an addict.
Harper Collins.

Stone, A.R., 1991. Will the real body please stand up? Cyberspace: first steps, pp.81-118.

Turkle, S., 2011. Life on the Screen. Simon and Schuster. 